\title{
RESPONSE OF A NEWLY RECLAIMED CALCAREOUS SOIL AT THE EASTERN RIM OF EL FAYOUM DEPRESSION TO AGROCHEMICAL AMENDMENT FOR SUSTAINING ITS AGRICULTURAL UTILIZATION
}

Atif A. Awadalla; Mohamed S.A. Ewees and Samir A.M. Moussa*

Soils and Water Dept., Fac. of Agric., El Fayoum University, Egypt

*Soils, Water and Environ. Res. Inst., Agric. Res. Center, Giza, Egypt

\section{ABSTRACT:}

Agricultural utilization of desert marginal soils at El Fayoum Governorate edges is of importance to support the local farmer incomes, particularly under the best and suitable management practices of land and available water resources. The choice a newly reclaimed soil encompassing by Eocene limestone at the eastern edge of Tamia district was a matter of concern in this work. It is a sandy clay loam in texture, slightly saline, nonsodic, and calcareous in nature with a subsurface diagnostic horizon of calcigypsic one, and classified as Typic Calcigypsids, fine loamy, mixed, heperthermic, moderately deep. According to a parametric system, it could be evaluated as moderately suitable (S2Ws3s4), with soil limitations of wetness, soil depth and $\mathrm{CaCO}_{3}$ content, with an intensity degree for each lies in the range of slight-moderate (rating $=90-80$ ).

The obtained analytical data pointed to a considerable decrease in soil productivity due to high $\mathrm{CaCO}_{3}$ content and low organic matter content as well as a relatively high soil $\mathrm{pH}$ value. These factors are the main reasons of deficiency for most plant nutritive elements, particularly phosphorus and zinc in the soil under study. Hence, suitable agrochemical amendments have to be applied to sustain its productivity and to minimize the possible adverse effects of both high $\mathrm{CaCO}_{3}$ content and soil $\mathrm{pH}$. Therefore, a field experiment was conducted on the chosen soil, where lentil plants (Lens esculenta c.v. Giza 9) were sown during the winter season of 2005-2006. The investigated soil plots were irrigated with the available irrigation water source (mixture of the Nile and drainage waters at a ratio of 1:1) in a randomized complete blocks design with three replicates. The agricultural management practices were conducted as usual, where elemental sulphur was applied to the soil plots (i.e., agrochemical soil amendment) at four rates (i.e., 0, 250, 500 and $750 \mathrm{~kg} \mathrm{~S}^{-1}$ ), while $\mathrm{Zn}$ was foliar sprayed on the grown plants (i.e., supporting Zn deficient) at three rates (i.e., 0, 450 and $\left.900 \mathrm{~g} \mathrm{fed}^{-1}\right)$.

The results showed that applied S and Zn, especially at their highest rates together, caused more pronounced increases in the vegetative growth parameters, i.e., number of bacterial nodules/plant, dry weight of bacterial nodules/plant, plant height, number of branches/plant and number of pods/plant. The corresponding relative increases at the highest applied rates of S and Zn (750 kg S/fed + $900 \mathrm{~g} \mathrm{Zn/fed)} \mathrm{were} \mathrm{92.61,} \mathrm{191.38,} \mathrm{34.27,} \mathrm{69.95}$ and $83.58 \%$ over the control treatment, respectively. Increase percentages in soil organic matter, $\mathrm{N}, \mathrm{P}, \mathrm{K}, \mathrm{Fe}, \mathrm{Mn}$ and $\mathrm{Zn}$ vs decrease percentage in soil $\mathrm{pH}$ occurred due to the dual application of $(750 \mathrm{~kg} \mathrm{~S} / \mathrm{fed}+900 \mathrm{~g} \mathrm{Zn} / \mathrm{fed})$ after 55 days from planting were 60.78, 65.02, 78.05, 54.14, 44.76, 51.83 and $119.74 \%$ vs- $10.62 \%$ over and below the control treatment, respectively.

At harvest, seed weights/plant or /fed, 1000 seed weight and seed protein $\%$ as well as N, P, K, S and $\mathrm{Zn}$ uptake by seed were also positively

Fayoum J. Agric. Res. \& Dev., Vol. 21, No.1, January, 2007 
affected, where the corresponding relative increases at the treatment of (750 $\mathrm{kg} \mathrm{S} / \mathrm{fed}+900 \mathrm{~g} \mathrm{Zn/fed)} \mathrm{reached} \mathrm{82.85,} \mathrm{71.59,} \mathrm{77.27,} \mathrm{42.28,} \mathrm{42.31,} \mathrm{87.88,}$ $28.06,71.79$ and $61.01 \%$ over the control, respectively. As a conclusion, it could be deduced that application of $S$ as a soil amendment at a rate of 750 $\mathrm{kg} / \mathrm{fed}$ in combination with any micronutrient deficient as foliar spray is important to sustain soil productivity and to obtain economically best crop yield attributes under such a soil calcareous in nature for avoiding a direct restrictive effect of $\mathrm{CaCO}_{3}$ on the nutrients released and their mobility towards plant roots. This is true, since the suggested sulphur efficiency at the recommended $\mathrm{S}$ rate for lentil seeds utilization of $\mathrm{N}, \mathrm{P}, \mathrm{K}, \mathrm{S}$ (macro) and $\mathrm{Zn}$ (micronutrients) was 105.47, 156.82, 88.60, 141.83 and $114.28 \%$, respectively.

Key words: Calcareous soil, limitations of soil productivity, elemental sulphur, Zn-foliar spray and lentil.

\section{INTRODUCTION:}

In the few last decades, soil survey data of the newly reclaimed soils at the desert areas, especially those calcareous in nature, pointed to a considerable decrease in their productivity. This is mainly due to high $\mathrm{CaCO}_{3}$ content and low organic matter content, which represented the main factors for widespread occurrence of essential plant nutrients deficiency, particularly phosphorus and some micronutrients for grown crops (Takker and Walker, 1993). Also, high levels of soil $\mathrm{pH}$ due to the occurrence of high $\mathrm{CaCO}_{3}$ content and low organic matter exert negative influence on the availability of these micronutrients (Basyouny, 2005).

Lentil is a protein rich food legume grown during the winter season in Egypt. Such legume crop is of biological nitrogen fixation and frequently response to sulphur fertilization due to their high S-requirement. Huang et al. (1992) reported that seed yield of lentil increased as inorganic sulphate concentration increased in the leaf tissue; indicating that the $\mathrm{S}$ nutritional status of lentil plants is of importance for obtaining a highest seed yield. The critical S concentration has been suggested as that which produces $90 \%$ of the maximum lentil yield $\left(0.045 \% \quad \mathrm{SO}_{4}-\mathrm{S}\right)$ at early flowering stage. In this connection, Singh et al. (2002) found that application of sulphur increased significantly yield attributes. Yield and yield attributes, seed protein content and total protein products increased significantly with increasing applied sulphur levels.

Many studies were carried out to investigate the beneficial effects of some materials as soil amendments, such as elemental sulphur, Shahin and Suliman (1998) reported that elemental sulphur is used to amend high $\mathrm{pH}$ soil conditions caused by either sodicity or high $\mathrm{CaCO}_{3}$ content, especially calcareous deposits. They found also that the blending of elemental sulphur with urea slowed down its transformation and reduced volatilization of $\mathrm{NH}_{3}$ to $20 \%$ of urea-N. Awad et al. (2000), Mostafa (2000) and Negm et al. (2002 a and b) clarified the importance of sulphur mixed with some organic wastes for improving the properties of calcareous soil and its productivity of grown plants due to increasing the efficiency of nutrients availability and mobility.

Technical choices of applying sulphur rates in combination with some other plant nutrients or organic manures through enough periods may be one of the most important investigations in the newly reclaimed calcareous soils of Egypt. The beneficial effects could be achieved through improving some soil

Fayoum J. Agric. Res. \& Dev., Vol. 21, No.1, January, 2007 


\section{RESPONSE OF A NEWLY RECLAIMED CALCAREOUS SOIL AT... 65}

physical and chemical properties, i.e., soil water stable aggregates, permeability, available moisture retention, bulk density, organic matter, soil $\mathrm{pH}$ and available nutrient contents. These favourable conditions are actually reflected on increasing use efficiency of water and nutrients uptake by plant, consequently leads to increase the vegetative growth and crop production (Awadalla et al., 2003 and Fathi et al., 2005). The later authors pointed out that application of $\mathrm{S}$ to alkaline soil media calcareous in nature enhanced the availability of phosphorus, which is the most nutrient limiting the growth of legumes in tropical environments. This may be due to the efficiency of rhizobium inoculation is influenced by a number of factors; one of these factors is the availability of phosphorus in soil. This means that released phosphorus is directly involved in lentil nutrition and hence improves leaf area development and photosynthesis, which enhances the root as well as shoot growth, plant height, pod number/plant and seed yield (Krishnareddy and Ahlawat, 1996; and Singh et al., 2000 and Tomar et al., 2000).

The essential roles of micronutrients in plant metabolism, as activators or co-factor in all vital processes of a plant, can not be ignored. This leads undoubtedly to an increase in crop production, which is considered as the main goal in this respect (El Kabbany et al., 1996). Moussa et al. (1998) reported that the micronutrients $(\mathrm{Fe}, \mathrm{Mn}$ and $\mathrm{Zn}$ ) enhanced the crop yield because of their beneficial effect on some bioprocesses, and in turn on the vegetative growth of plants. Ghaly et al. (1992) found that application of Zn-EDTA to calcareous soil increased the crop yield. In addition, micronutrients application in combination with elemental sulphur as a soil amendment to soil is considered to be of significant importance if high yields aimed to be produced. Salama et al., (2003) found that Zn element at a rate of $12 \% \mathrm{Zn}$ chelate plays an important role for increasing the growth parameters of wheat, i.e., plant height, spike length and number of spikelets/spike as well as biological yield and its content of N, P, K and Zn.

Wahdan et al. (2006) found that the beneficial effects of elemental sulphur in combination with some micronutrients were actually reflected on increasing the grain and straw yields of wheat plants grown on a calcareous soil. They added that these positive effects were more attributed to improve the efficiency of micronutrients availability, mobility and uptake by plant roots. Moreover, the micronutrient accumulation in the plant organs tissues is closely related to the corresponding available contents of this nutrient in the treated soils. Therefore, The current work aimed at identifying the effect of agrochemical amendment using an elemental sulphur (S) and zinc ( $\mathrm{Zn})$, added at different rates as S-soil application and $\mathrm{Zn}$-foliar spray, on lentil yield and its seed quality. Also, the associated changes in some soil properties as affected by applied treatments will be a matter of concern in this investigation.

\section{MATERIALS AND METHODS: a. Materials:}

The current work was executed on a newly reclaimed calcareous soil at the eastern rim of Tamia district, El Fayoum Governorate; some of its physical, chemical and fertility characteristics, as profile mean values, were determined according to the standard methods undertaken by Jackson (1973) and Black $\boldsymbol{e t}$ al. (1965), and results of determinations are presented in Table (1).

Fayoum J. Agric. Res. \& Dev., Vol. 21, No.1, January, 2007 
Table (1): Some physical and chemical properties of the experimental soil (as profile mean values).

\begin{tabular}{|c|c|c|c|c|c|c|}
\hline \multicolumn{2}{|c|}{ Soil characteristics } & Value & \multicolumn{3}{|c|}{ Soil characteristics } & Value \\
\hline \multirow{2}{*}{\multicolumn{2}{|c|}{$\begin{array}{l}\text { Particle size distribution \%: } \\
\text { Sand }\end{array}$}} & & \multicolumn{3}{|c|}{ Soluble cations (soil paste, $m$ molcL $L^{-1}$ ): } & \\
\hline & & 48.83 & \multicolumn{3}{|c|}{$\mathrm{Ca}^{2+}$} & 23.25 \\
\hline \multicolumn{2}{|l|}{ Silt } & 23.65 & \multicolumn{3}{|l|}{$\mathrm{Mg}^{2+}$} & 10.63 \\
\hline \multicolumn{2}{|l|}{ Clay } & 27.52 & \multicolumn{3}{|l|}{$\mathrm{Na}^{+}$} & 29.34 \\
\hline \multicolumn{2}{|l|}{ Textural class } & SCL* & \multicolumn{3}{|l|}{$\mathrm{K}^{+}$} & 0.75 \\
\hline \multicolumn{2}{|c|}{ Soil chemical properties: } & & \multicolumn{3}{|c|}{ Soluble anoions (soil paste, $m$ molcL $L^{-1}$ ) } & \\
\hline \multicolumn{2}{|c|}{ Soil pH (1.25 soil water suspension) } & 8.32 & \multicolumn{3}{|l|}{$\mathrm{CO}_{3}{ }^{2-}$} & 0.00 \\
\hline \multicolumn{2}{|l|}{$\mathrm{CaCO}_{3} \%$} & 24.90 & \multicolumn{3}{|l|}{$\mathrm{HCO}_{3}^{-}$} & 2.85 \\
\hline \multicolumn{2}{|l|}{ Gypsum \% } & 5.67 & \multicolumn{3}{|l|}{$\mathrm{Cl}^{-}$} & 37.67 \\
\hline \multicolumn{2}{|l|}{ Organic matter $\%$} & 0.48 & \multicolumn{3}{|l|}{$\mathrm{SO}_{4}^{2-}$} & 23.45 \\
\hline \multicolumn{2}{|c|}{ ECe $(\mathrm{dS} / \mathrm{m}$, soil paste extract) } & 6.32 & \multicolumn{3}{|l|}{ ESP } & 7.46 \\
\hline \multirow{2}{*}{\multicolumn{2}{|c|}{$\frac{\text { Available macronutrients }\left(\mathrm{mgkg}^{-1}\right)}{\mathrm{N}}$}} & & \multicolumn{3}{|c|}{ Available micronutrients $\left(\mathrm{mgkg}^{-1}\right)$ : } & \\
\hline & & 43.52 & \multicolumn{3}{|c|}{$\mathrm{Fe}$} & 5.21 \\
\hline \multicolumn{2}{|l|}{$\mathrm{P}$} & 4.71 & \multicolumn{3}{|l|}{$\mathrm{Mn}$} & 2.94 \\
\hline \multicolumn{2}{|l|}{$\mathrm{K}$} & 324.50 & \multicolumn{3}{|l|}{$\mathrm{Zn}$} & 0.72 \\
\hline \multicolumn{7}{|c|}{$\begin{array}{l}\text { Critical levels of available nutrients in soil }\left(\mathrm{mgkg}^{-1}\right) \text {, undertaken by Lindsay and Norvell (1978) and } \\
\text { Page et al. (1982). }\end{array}$} \\
\hline Nutrient level & $\mathrm{N}$ & $\mathrm{P}$ & $\mathrm{K}$ & $\mathrm{Fe}$ & $\mathrm{Mn}$ & $\mathrm{Zn}$ \\
\hline Low & $<40.0$ & $<5.0$ & $<85.0$ & $<4.0$ & $<2.0$ & $<1.0$ \\
\hline Medium & $40.0-80.0$ & $5.0-10.0$ & $85.0-170.0$ & $4.0-6.0$ & $2.0-5.0$ & $1.0-2.0$ \\
\hline High & $>80.0$ & $>10.0$ & $>170$ & $>6.0$ & $>5.0$ & $>2.0$ \\
\hline
\end{tabular}

* Sandy clay loam

The obtained analytical data pointed to a considerable decrease in soil fertility due to high $\mathrm{CaCO}_{3}$ content and low organic matter content as well as a relatively high soil $\mathrm{pH}$ value. These factors are the main reasons of deficiency for most plant nutritive elements, particularly phosphorus and zinc in the soil under study.

\section{b. Experimental work:}

So, it should be executed a suitable agrochemical amendments to sustain its fertility and to minimize such possible adverse effects. Hence, a field experiment was conducted on the chosen soil site, where lentil (Lens esculenta c.v. Giza 9) was sown during the winter season of 2005-2006. The investigated soil plots were irrigated with available irrigation water source (mixture of the Nile and drainage water at a ratio of 1:1) in randomized complete block design, with three replicates. The chemical analysis of the water source was executed according to Black $\boldsymbol{e t}$ al. (1965) and presented in Table (2). The agricultural management practices were conducted as usual, where elemental sulphur was applied to the soil plots (i.e., agrochemical soil amendment) at four rates (i.e., 0, 250, 500 and $750 \mathrm{~kg}$ $\mathrm{S} \mathrm{fed}{ }^{-1}$ ), while $\mathrm{Zn}$ was foliar sprayed on the grown plants (i.e., supporting $\mathrm{Zn}$ deficient) at three rates (i.e., 0,450 and $900 \mathrm{~g} \mathrm{fed}^{-1}$ ). 
RESPONSE OF A NEWLY RECLAIMED CALCAREOUS SOIL AT... 67

Table (2): Water characteristics of the used irrigation source (drainage water).

\begin{tabular}{|l|c|}
\hline \multicolumn{1}{|c|}{ Water characteristics } & Value \\
\hline Water $\mathrm{pH}$ & 7.32 \\
\hline ECiw $\left(\mathrm{dSm}^{-1}\right)$ & 1.35 \\
\hline Total dissolved salts $\left(\mathrm{mgL}^{-1}\right)$ & 864.00 \\
\hline Soluble ions $\left(\mathrm{m} \mathrm{molc}^{-1}\right):$ & \\
\hline $\mathrm{Ca}^{++}$ & 2.13 \\
$\mathrm{Mg}^{++}$ & 1.92 \\
$\mathrm{Na}^{+}$ & 9.25 \\
$\mathrm{~K}^{+}$ & 0.60 \\
$\mathrm{CO}_{3}^{--}$ & 0.00 \\
$\mathrm{HCO}_{3-}$ & 5.03 \\
$\mathrm{Cl}^{-}$ & 6.72 \\
$\mathrm{SO}_{4}^{--}$ & 2.15 \\
\hline Sodium adsorption ratio (SAR) & 6.50 \\
\hline Residual sodium carbonate (RSC) & 0.98 \\
\hline Irrigation water suitability degree & $\mathrm{C} 2 \mathrm{~S} 2$ \\
\hline
\end{tabular}

Both S-soil application and Zn-foliar spray were added either solely or in combined treatments. The elemental sulphur was thoroughly mixed with the surface soil $(0-25 \mathrm{~cm})$ during soil preparation processes, while $\mathrm{Zn}$ was foliar sprayed on the grown plants in the form of zinc sulphate $(22 \% \mathrm{Zn})$ after 45 days from planting. The applied $\mathrm{Zn}$ rates in the foliar nutrition solutions were 1.50 and $3.00 \mathrm{~g} / \mathrm{L}$, and sprayed at one volume of $300 \mathrm{~L} / \mathrm{fed}$. The lentil seeds were sown on the $5^{\text {th }}$ November 2005 in fixed plots of $10.5 \mathrm{~m}^{2}(3 \times 3.5 \mathrm{~m})$ for each one. Recommended nitrogen fertilizer dose belongs to legume (15 kg $\mathrm{N} /$ fed as calcium nitrate, $15.5 \% \mathrm{~N}$ ) was added to activate the nodulation. Also, $30 \mathrm{~kg} \mathrm{fed}^{-1} \mathrm{P}_{2} \mathrm{O}_{5}$ as superphosphate $\left(15 \% \mathrm{P}_{2} \mathrm{O}_{5}\right)$ and $24 \mathrm{~kg} \mathrm{fed}^{-1} \mathrm{~K}_{2} \mathrm{O}$ as potassium sulphate $\left(48 \% \mathrm{~K}_{2} \mathrm{O}\right)$ were added before planting. The common cultivation practices were followed up till plant harvesting on the $2^{\frac{\text { nd }}{}}$ of May 2006.

\section{c. Methods of analysis:}

Soil samples were collected from the surface layers $(0-35 \mathrm{~cm})$ of each plot on the $55^{\text {th }}$ day of planting, and were analyzed to determine soil $\mathrm{pH}$ and organic matter content (after harvest) according to Page et al. (1982). In addition, available $\mathrm{N}, \mathrm{P}$ and $\mathrm{K}$ were extracted by $1 \%$ potassium sulphate, 0.5 $\mathrm{M}$ sodium bicarbonate and $1 \mathrm{~N}$ ammonium acetate, respectively, and were determined according to Jackson (1973). Also, available micronutrients (Fe, $\mathrm{Mn}$ and $\mathrm{Zn}$ ) were extracted using ammonium bicarbonate DTPA extract according to Soltanpour and Schwab (1977), and measured by using the Atomic Absorption Spectrophotometer.

At the same period (on $55^{\text {th }}$ day), some plants were selected from each plot to determine some vegetative growth parameters, i.e., number of bacterial nodules/plant, dry weights of bacterial nodules/plant, plant height, number of branches/plant and number of pods/plant. In addition, at harvest, seed weights/plant or $\mathrm{kg} / \mathrm{fed}$ and 1000 seed weight were determined. After that, lentil seed samples of each treatment were mixed to form composite samples and ground using a micro-mill grinder, then subjected to a wet digestion with

Fayoum J. Agric. Res. \& Dev., Vol. 21, No.1, January, 2007 
$\mathrm{H}_{2} \mathrm{SO}_{4}$ and $\mathrm{H}_{2} \mathrm{O}_{2}$ according to Sommers and Nelson (1972) to determine $\mathrm{N}$, $\mathrm{P}, \mathrm{K}, \mathrm{S}$ and $\mathrm{Zn}$ uptake by lentil seed according to Chapman and Pratte (1961) as well as seed protein $\%$ or as $\mathrm{kg} / \mathrm{fed}$. The micronutrient contents were measured by using the Atomic Absorption Spectrophotometer.

The data obtained were subjected to variance analysis using least significant difference (L.S.D.), which was used to compare the main treatments and interaction effects at 0.05 according to Snedecor and Cochran (1980).

\section{RESULTS AND DISCUSSION:}

Agriculture utilization of marginal desert soils located on El Fayoum depression rims is of importance to support the local farmer's inputs, particularly under the best management practices of land and available water resources.

\section{A general view on the initial state of the experimental soil:}

a. Soil morphology and some physical properties:

The soil site under consideration is mainly encompassing the eastern desert rim of El Fayoum depression and developed on the Eocene limestone, as sources of soil parent materials, under climatic conditions of long hot rainless summer and short mild winter. Soil colour is pale brown (10YR 6/3) in the surface layer (Ap, 0-25 cm) underlain brownish yellow (10YR 6/8) owing to the occurrence of mottling phenomena of reddish brown patches (2.5YR 4/4) in the upper oxidized zone.

The obtained results in Table (1) reveal that soil texture tended to be medium grade, where the clay content was less than $30 \%$. Soil structure was granular in topsoil and subangular blocky in the subsoil layers, which reflected the signs of the pedogenic formations of calci-gypsic concretions (Byz, 25-60 $\mathrm{cm}$ ) that originated from sediment origins (Cyz, 60-95 cm), due to the intensive of geo-chemical weathering under the ancient aquic conditions and the environments of depositional regime. These pedo-secondary formations throughout the studied soil profile could be mixed in the form of calci-gypsic concretions. Moreover, these accumulations in the subsurface horizon are enough qualified the requirements of diagnostic horizon formation such as calcigypsic one.

\section{b. Some soil chemical properties and nutrients status:}

Concerning the studied soil chemical properties, data illustrated in Table (1) indicate that soil organic matter content is relatively low, may be due to the mineral nature of soil deposits and the prevailing hot and arid climatic conditions. In general, the relatively low values of soil ECe, $\mathrm{pH}$ and ESP (i.e., $<4 \mathrm{dS} / \mathrm{m},<8.5$ and $<15$, respectively) led to classify the studied soil as nonsaline and non-sodic soil. It is noteworthy that the studied recorded available contents of $\mathrm{N}, \mathrm{P}, \mathrm{K}, \mathrm{Fe}, \mathrm{Mn}$ and $\mathrm{Zn}$, in general, lie at the medium levels, with exception of $\mathrm{P}$ and $\mathrm{Zn}$ contents which lie at the low level (Lindsay and Norvell, 1978 and Page et al., 1982), as shown in Table (1). Undoubtedly, Ssoil application and $\mathrm{Zn}$-foliar spray will be a matter of concern in this work,

\section{c. Soil taxonomy and evaluation:}

Taxonomic unit of the current experimental soil is identified and named according to the results of soil morphological and physio-chemical characteristics at the family level according to Soil Survey Staff (1999) as Typic Calcigypsids, fine loamy, mixed, hyperthermic and moderately deep. Also, according to a parametric system undertaken by Sys and Verheye 
RESPONSE OF A NEWLY RECLAIMED CALCAREOUS SOIL AT... 69

(1978), the intensity degrees of soil limitations and suitability categories for the studied soil were calculated and presented in Table (3).

Table (3): Soil limitations and rating indices for evaluating the studied soil at the current experiment.

\begin{tabular}{|c|c|c|c|c|c|c|c|c|c|}
\hline \multirow[b]{2}{*}{ 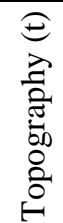 } & \multirow[b]{2}{*}{$\begin{array}{l}3 \\
0 \\
0 \\
0 \\
0 \\
0 \\
3\end{array}$} & \multicolumn{4}{|c|}{$S$} & \multirow[b]{2}{*}{ 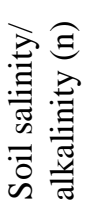 } & \multirow[b]{2}{*}{ 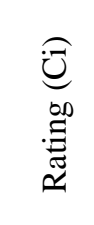 } & \multirow[b]{2}{*}{ 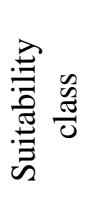 } & \multirow[b]{2}{*}{ 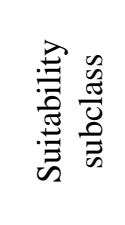 } \\
\hline & & 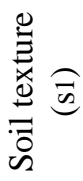 & 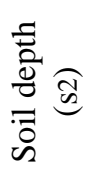 & $\bigcup_{0}^{\infty} \widehat{\tilde{E}}$ & 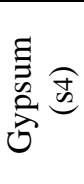 & & & & \\
\hline 100 & 90 & 95 & 90 & 80 & 100 & 98 & 60.33 & $\mathrm{~S} 2$ & $\mathrm{~S} 2 \mathrm{ws} 2 \mathrm{~s} 3$ \\
\hline
\end{tabular}

It is cleared from data obtained that wetness, soil depth and $\mathrm{CaCO}_{3}$ content are the most effective limitations for soil productivity. This means that oil wetness is negatively affected by the moderate soil depth $(95 \mathrm{~cm}$ depth underlain limestone bedrock) due to the limitation of water downward movement and possibly the adverse conditions of soil moisture regime. Also, the relative high $\mathrm{CaCO}_{3}$ content is more effective limitation for soil productivity, due to its restrictive effect on nutrients availability and mobility towards plant roots and in turn their uptake. Also, the experimental soil could be evaluated as moderately suitable ( $\mathrm{S} 2 \mathrm{ws} 3 \mathrm{~s} 4)$, with an intensity degree for each of wetness, soil depth and $\mathrm{CaCO}_{3}$ content, as soil limitations, lies in the range of slight-moderate (rating $=90-80$ ).

\section{Available irrigation water source:}

Usage of such a mixture of irrigation sources between the Nile and drainage water, with a ratio of $1: 1$, is considered one of the most additional developments for agricultural local policy, which have accelerated the direction towards soil agricultural utilization in El Fayoum region. According to the water salinity and sodicity classes undertaken by Ayers and Westcot (1985), data in Table (2) indicated that the used irrigation water source (a mixture of the Nile and drainage water) lies in the second category of $\mathrm{C}_{2} \mathrm{~S}_{2}$, where ECiw and SAR values lay within the range of 0.75-3.00 dS/m and > 6.0 , respectively.

III. Effect of S-soil application and Zn-foliar spray on some soil properties:

The resultant agrochemical properties after either on the $55^{\text {th }}$ day (for soil $\mathrm{pH}$ ) and about six months of cultivation (for organic matter content) due to $\mathrm{S}$ soil application and $\mathrm{Zn}$-foliar spray are presented in Table (4). It could be noticed that values of soil organic matter content exhibited gradually pronounced increases with increasing the applied rates of S and $\mathrm{Zn}$, while the reverse was true for $\mathrm{pH}$ values. The corresponding greatest and lowest percentages were 60.78 and $10.62 \%$, respectively, achieved due to application of the highest rates of $\mathrm{S}$ and $\mathrm{Zn}$ together $(750 \mathrm{~kg} \mathrm{~S} / \mathrm{fed}+900 \mathrm{~g} \mathrm{Zn} / \mathrm{fed})$. These positive changes in soil $\mathrm{pH}$ of rhizosphere occurred as a result of bio-oxidation of applied $\mathrm{S}$ to $\mathrm{SO}_{4}{ }^{2-}$, which resulted in reduction of soil $\mathrm{pH}$.

Fayoum J. Agric. Res. \& Dev., Vol. 21, No.1, January, 2007 
Table (4): Organic matter content (at harvest), $\mathrm{pH}$ and some available nutrient contents on the $55^{\text {th }}$ day as affected by $\mathrm{S}$-soil application and $\mathrm{Zn}$-foliar spray.

\begin{tabular}{|c|c|c|c|c|c|c|c|c|c|}
\hline \multicolumn{2}{|c|}{ Treatment } & \multirow{3}{*}{$\begin{array}{c}\text { Organic } \\
\text { matter } \\
\%\end{array}$} & \multirow{3}{*}{$\begin{array}{c}\text { Soil } \\
\mathrm{pH} \\
(1: 2.5)\end{array}$} & \multirow{2}{*}{\multicolumn{3}{|c|}{$\begin{array}{c}\text { Macronutrients }(\mathrm{mg} / \mathrm{kg} \\
\text { soil) }\end{array}$}} & \multirow{2}{*}{\multicolumn{3}{|c|}{ Micronutrients ( $\mathrm{mg} / \mathrm{kg}$ soil) }} \\
\hline \multirow{2}{*}{$\begin{array}{c}\text { S-soil } \\
(\mathrm{kg} / \mathrm{fed})\end{array}$} & \multirow{2}{*}{$\begin{array}{c}\text { Zn-foliar } \\
(\mathrm{g} / \mathrm{fed})\end{array}$} & & & & & & & & \\
\hline & & & & $\mathrm{N}$ & $\mathrm{P}$ & $\mathrm{K}$ & $\mathrm{Fe}$ & $\mathrm{Mn}$ & $\mathrm{Zn}$ \\
\hline \multirow{3}{*}{0} & $0 *$ & 0.51 & 8.29 & 48.75 & 4.92 & 342.15 & 5.63 & 3.01 & 0.76 \\
\hline & 450 & 0.57 & 8.21 & 53.08 & 5.13 & 366.46 & 6.07 & 3.24 & 0.81 \\
\hline & 900 & 0.61 & 8.14 & 59.69 & 5.24 & 375.13 & 6.16 & 3.39 & 0.84 \\
\hline \multicolumn{2}{|c|}{ Mean } & 0.56 & 8.21 & 53.84 & 5.09 & 361.24 & 5.95 & 3.21 & 0.80 \\
\hline \multirow{3}{*}{250} & 0 & 0.56 & 7.95 & 52.34 & 5.96 & 363.08 & 6.33 & 3.59 & 0.91 \\
\hline & 450 & 0.65 & 7.89 & 58.02 & 6.07 & 376.25 & 6.52 & 3.66 & 0.96 \\
\hline & 900 & 0.69 & 7.83 & 64.10 & 6.15 & 389.78 & 6.71 & 3.72 & 1.02 \\
\hline \multicolumn{2}{|c|}{ Mean } & 0.63 & 7.89 & 58.15 & 6.06 & 376.37 & 6.52 & 3.66 & 0.96 \\
\hline \multirow{3}{*}{500} & 0 & 0.59 & 7.76 & 58.73 & 6.92 & 391.39 & 6.85 & 3.95 & 1.23 \\
\hline & 450 & 0.69 & 7.69 & 64.15 & 7.17 & 402.02 & 6.91 & 4.07 & 1.29 \\
\hline & 900 & 0.74 & 7.61 & 69.84 & 7.35 & 436.45 & 7.09 & 4.13 & 1.34 \\
\hline \multicolumn{2}{|c|}{ Mean } & 0.67 & 7.69 & 64.24 & 7.14 & 409.95 & 6.95 & 4.05 & 1.29 \\
\hline \multirow{3}{*}{750} & 0 & 0.62 & 7.53 & 66.03 & 8.54 & 474.56 & 7.95 & 4.46 & 1.56 \\
\hline & 450 & 0.73 & 7.48 & 73.97 & 8.69 & 489.77 & 8.02 & 4.51 & 1.61 \\
\hline & 900 & 0.82 & 7.41 & 80.45 & 8.76 & 527.39 & 8.15 & 4.57 & 1.67 \\
\hline \multicolumn{2}{|c|}{ Mean } & 0.72 & 7.47 & 73.48 & 8.66 & 497.24 & 8.04 & 4.51 & 1.61 \\
\hline \multirow{3}{*}{$\begin{array}{l}\text { L.S.D. at } \\
0.05\end{array}$} & $\mathrm{~S}$ & 0.04 & 0.18 & 1.56 & 0.41 & 11.07 & 0.29 & 0.27 & 0.14 \\
\hline & $\mathrm{Zn}$ & 0.10 & 0.51 & 1.92 & 0.32 & 20.73 & 0.12 & 0.50 & 0.30 \\
\hline & $\mathrm{S} \times \mathrm{Zn}$ & 0.03 & 0.05 & 2.10 & 0.91 & 12.54 & 0.76 & 0.07 & 0.12 \\
\hline
\end{tabular}

*The control treatment

The resultant favourable conditions enhanced the availability of nutrients in the soil, and in turn encountered the vegetative growth and hence increased organic matter accumulation at harvest. These results are in harmony with those of Abd El Halim (2001) and Fathi et al. (2005) who reported that application of sulphur or increasing its rate resulted in an increase in soil organic matter content, this may be due to sulphur enhanced or accelerate the decomposition of plant residues. Such soil medium was superior for lowering soil $\mathrm{pH}$ values from 8.29 to $7.86,7.61$ and 7.41 at $\mathrm{S}$ rates 250,500 and 750 $\mathrm{kg} / \mathrm{fed}$ in combination with $900 \mathrm{~g} \mathrm{Zn} / \mathrm{fed}$, respectively. These findings are in harmony to those of Johnson and Tucher (1982), since the studied calcareous soil is slightly alkaline with a light buffer capacity of $\mathrm{CaCO}_{3}$, and the acidity that is produced is beneficial. In addition, nutrients availability is mostly dependent upon biological activity that is markedly affected by soil temperature, moisture, aeration and original soil $\mathrm{pH}$ (Jones et al., 1991). The relative increases in the released nutrients of $\mathrm{N}, \mathrm{P}, \mathrm{K}, \mathrm{Fe}, \mathrm{Mn}$ and $\mathrm{Zn}$ at the highest rates of applied $\mathrm{S}$ and $\mathrm{Zn}$ of the combined treatment $(750 \mathrm{~kg} \mathrm{~S} / \mathrm{fed}+$ $900 \mathrm{~g} \mathrm{Zn/fed)} \mathrm{reached} 65.02,78.05,54.14,44.76,51.83$ and $119.74 \%$ over the control treatment, respectively.

\section{Effect of S-soil application and Zn-foliar spray on the vegetative growth parameters:}

Under such desert conditions, adding S-soil application to the calcareous soil cultivated with the tested lentil crop showed that the highest rates of $S$ and $\mathrm{Zn}$ together recorded the highest averages of lentil vegetative growth parameters, as shown in Table (5).

Fayoum J. Agric. Res. \& Dev., Vol. 21, No.1, January, 2007 
RESPONSE OF A NEWLY RECLAIMED CALCAREOUS SOIL AT... 71

Table (5): Number of bacterial nodules/plant, dry weights of bacterial nodules/plant, plant height, number of branches/plant and number of pods/plant on the $55^{\text {th }}$ day as affected by $\mathrm{S}$-soil application and $\mathrm{Zn}$-foliar spray.

\begin{tabular}{|c|c|c|c|c|c|c|}
\hline \multicolumn{2}{|c|}{ Treatment } & \multirow{2}{*}{$\begin{array}{c}\text { No. of } \\
\text { nodules/plant }\end{array}$} & \multirow{2}{*}{$\begin{array}{c}\text { Dry weight } \\
\text { of nodules/ } \\
\text { plant }(\mathrm{g})\end{array}$} & \multirow{2}{*}{$\begin{array}{c}\text { Plant height } \\
(\mathrm{cm})\end{array}$} & \multirow{2}{*}{$\begin{array}{c}\text { No. of } \\
\text { branches/ } \\
\text { plant }\end{array}$} & \multirow{2}{*}{$\begin{array}{c}\text { No. of } \\
\text { pods/plant }\end{array}$} \\
\hline $\begin{array}{c}\text { S-soil } \\
(\mathrm{kg} / \mathrm{fed})\end{array}$ & $\begin{array}{c}\text { Zn-foliar } \\
\text { (g/fed) }\end{array}$ & & & & & \\
\hline \multirow{3}{*}{0} & $0 *$ & 21.52 & 0.58 & 39.28 & 2.13 & 22.53 \\
\hline & 450 & 23.95 & 0.65 & 40.30 & 2.18 & 23.02 \\
\hline & 900 & 26.75 & 0.70 & 40.74 & 2.23 & 24.15 \\
\hline \multicolumn{2}{|c|}{ Mean } & 24.07 & 0.64 & 40.12 & 2.18 & 23.23 \\
\hline \multirow{3}{*}{250} & 0 & 25.98 & 0.86 & 41.61 & 2.36 & 28.97 \\
\hline & 450 & 29.54 & 0.91 & 42.32 & 2.43 & 30.11 \\
\hline & 900 & 32.96 & 0.98 & 43.55 & 2.49 & 32.43 \\
\hline \multicolumn{2}{|c|}{ Mean } & 29.43 & 0.92 & 42.49 & 2.43 & 30.50 \\
\hline \multirow{3}{*}{500} & 0 & 29.35 & 0.97 & 44.05 & 2.65 & 33.81 \\
\hline & 450 & 32.36 & 1.06 & 45.16 & 2.71 & 35.78 \\
\hline & 900 & 36.54 & 1.29 & 47.38 & 2.79 & 36.79 \\
\hline \multicolumn{2}{|c|}{ Mean } & 32.75 & 1.12 & 45.53 & 2.73 & 35.46 \\
\hline \multirow{3}{*}{750} & 0 & 35.63 & 1.21 & 48.52 & 3.23 & 38.40 \\
\hline & 450 & 38.07 & 1.45 & 50.31 & 3.35 & 39.54 \\
\hline & 900 & 41.45 & 1.69 & 52.74 & 3.62 & 41.36 \\
\hline \multicolumn{2}{|c|}{ Mean } & 38.38 & 1.45 & 50.52 & 3.40 & 39.77 \\
\hline \multirow{3}{*}{$\begin{array}{l}\text { L.S.D. at } \\
0.05\end{array}$} & $\mathrm{~S}$ & 1.94 & 0.23 & 0.43 & 0.41 & 1.19 \\
\hline & $\mathrm{Zn}$ & 2.59 & 0.32 & 1.34 & 0.73 & 2.34 \\
\hline & $\mathrm{S} \times \mathrm{Zn}$ & 3.24 & 0.13 & 1.11 & 0.51 & 1.23 \\
\hline
\end{tabular}

*The control treatment

These vegetative growth parameters were represented by number of bacterial nodules/plant, dry weights of nodules/plant, plant height, number of branches/plant and number of pods/plant. The corresponding increase percentages were $92.61,191.38,34.27,69.95$ and 83.58, respectively, achieved due to application of at the highest rates of $\mathrm{S}$ and $\mathrm{Zn}$ at the combined treatment $(750 \mathrm{~kg} \mathrm{~S} / \mathrm{fed}+900 \mathrm{~g} \mathrm{Zn/fed})$ over the control treatment, respectively. These beneficial responses are possibly due to the positive role of rhyzobia in providing the legume plants with adequate requirements of nitrogen with encouragement of S application.

$V$. Effect of S-soil application and Zn-foliar spray on the lentil seed yield and its quality:

Data of lentil seed yield and its quality are presented in Table (6), and show that the seed yield was significantly increased at all the S-soil application and $\mathrm{Zn}$-foliar spray treatments as compared to the control treatment. The increases insignificantly graduated from the low to the higher rates of applied $\mathrm{Zn}$ without addition of $\mathrm{S}$. The highest rates of $\mathrm{S}(750 \mathrm{~kg} / \mathrm{fed})$ and $\mathrm{Zn}(900 \mathrm{~g} / \mathrm{fed})$ together caused the highest values of seed weight/plant and yield/fed, which reached $13.75 \mathrm{~g}$ and $914.02 \mathrm{~kg}$, respectively with increase percentages of 82.85 and $71.59 \%$, respectively, as compared to the control treatment.

Fayoum J. Agric. Res. \& Dev., Vol. 21, No.1, January, 2007 
Table (6): Seed weights/plant or yield/fed, 1000 seed weight, seed protein $\%$ or $\mathrm{kg} / \mathrm{fed}$ at harvest as affected by $\mathrm{S}$-soil application and $\mathrm{Zn}$-foliar spray.

\begin{tabular}{|c|c|c|c|c|c|c|}
\hline \multicolumn{2}{|c|}{ Treatment } & \multirow{2}{*}{$\begin{array}{c}\text { Seed } \\
\text { weights/plant } \\
(\mathrm{g})\end{array}$} & \multirow{2}{*}{$\begin{array}{c}\text { Seed } \\
\text { weights/fed } \\
(\mathrm{kg})\end{array}$} & \multirow{2}{*}{$\begin{array}{l}1000 \text { seed } \\
\text { weight }(\mathrm{g})\end{array}$} & \multicolumn{2}{|c|}{ Seed protein } \\
\hline $\begin{array}{c}\text { S-soil } \\
\text { (kg/fed) }\end{array}$ & $\begin{array}{c}\text { Zn-foliar } \\
\text { (g/fed) }\end{array}$ & & & & $(\%)$ & $(\mathrm{Kg} / \mathrm{fed})$ \\
\hline \multirow{3}{*}{0} & 0* & 7.52 & 532.67 & 23.76 & 17.88 & 95.24 \\
\hline & 450 & 7.93 & 575.35 & 25.74 & 18.31 & 105.35 \\
\hline & 900 & 8.14 & 586.45 & 27.01 & 19.06 & 111.78 \\
\hline \multicolumn{2}{|c|}{ Mean } & 7.86 & 564.82 & 25.50 & 18.42 & 104.12 \\
\hline \multirow{3}{*}{250} & 0 & 8.77 & 616.72 & 29.13 & 20.13 & 124.15 \\
\hline & 450 & 8.96 & 653.95 & 32.45 & 21.06 & 137.72 \\
\hline & 900 & 9.23 & 713.25 & 34.05 & 21.31 & 151.99 \\
\hline \multicolumn{2}{|c|}{ Mean } & 8.99 & 661.31 & 31.89 & 20.83 & 137.95 \\
\hline \multirow{3}{*}{500} & 0 & 9.99 & 764.36 & 35.27 & 21.75 & 166.25 \\
\hline & 450 & 10.62 & 792.07 & 36.09 & 22.31 & 176.72 \\
\hline & 900 & 11.09 & 804.29 & 37.47 & 22.56 & 181.45 \\
\hline \multicolumn{2}{|c|}{ Mean } & 10.57 & 786.91 & 36.28 & 22.21 & 174.81 \\
\hline \multirow{3}{*}{750} & 0 & 12.52 & 837.85 & 38.56 & 23.69 & 198.49 \\
\hline & 450 & 13.03 & 893.76 & 40.78 & 24.44 & 218.43 \\
\hline & 900 & 13.75 & 914.02 & 42.12 & 25.44 & 232.53 \\
\hline \multicolumn{2}{|c|}{ Mean } & 13.10 & 881.88 & 40.49 & 24.52 & 216.48 \\
\hline \multirow{3}{*}{$\begin{array}{l}\text { L.S.D. at } \\
0.05\end{array}$} & $\mathrm{~S}$ & 0.66 & 64.71 & 0.75 & 0.36 & 12.34 \\
\hline & $\mathrm{Zn}$ & 1.21 & 96.22 & 1.33 & 0.76 & 21.31 \\
\hline & $\mathrm{S} \times \mathrm{Zn}$ & 0.77 & 33.21 & 0.92 & 0.32 & 10.03 \\
\hline
\end{tabular}

*The control treatment

Concerning lentil seed quality, data in Table (6) show insignificant increases in values of 1000 seed weight $(\mathrm{g})$ and seed protein \% due to $\mathrm{Zn}$ application. The increase seemed more obvious with increasing rate of the applied Zn. Similar increases occurred due to application of S, which might exert a positive role in activating rhyzobia that providing the legume plants with adequate requirements of bio-fixed nitrogen. The highest increase percentages in weight of 1000 seed and protein content \% were 77.27 and 42.28 , respectively, recorded at the highest rates of applied $\mathrm{S}$ and $\mathrm{Zn}$ at the combined treatment $(750 \mathrm{~kg} \mathrm{~S} / \mathrm{fed}+900 \mathrm{~g} \mathrm{Zn/fed})$. Similar results were obtained by Varavipour et al. (1999) who studied crop yield and its quality as affected with S application to Typic Ustochrept and found that $8.92 \mathrm{mg} \mathrm{S} / \mathrm{kg}$ soil represented an optimum rate for overall yield and quality of crop.

VI. Effect of S-soil application and Zn-foliar spray on seed contents of some nutrients:

\section{a. Seed contents of the studied nutrients:}

The successful diagnosis of nutritional status of any crop is a function of the relationship between growth at a certain stage of development and crop yield response. The magnitudes of the available nutrient contents in soil (Table, 4) seemed to be as seed contents of N, P, K, S and Zn (Table, 7). The highest nutrient contents were attained due to the highest rates of applied $S$ and $\mathrm{Zn}$ together, which exert the lowest soil $\mathrm{pH}$ value (7.41), possibly due to the beneficial effects of produced acidity $\left(\mathrm{H}^{+}\right.$ions) on enhancing nutrients availability. Such favourable conditions also resulted in increasing the net

Fayoum J. Agric. Res. \& Dev., Vol. 21, No.1, January, 2007 
RESPONSE OF A NEWLY RECLAIMED CALCAREOUS SOIL AT... 73

photosynthesis, stomata conductance and transpiration rate (Naire and Khuble, 1990).

Table (7): N, P, K, S and Zn uptake by lentil seed at harvest as affected by S-soil application and Zn-foliar spray.

\begin{tabular}{|c|c|c|c|c|c|c|}
\hline \multicolumn{2}{|c|}{ Treatment } & \multicolumn{5}{|c|}{ Lentil seed contents of some nutrients (mg/kg) } \\
\hline \multirow{2}{*}{$\begin{array}{c}\text { S-soil } \\
\text { (kg/fed) }\end{array}$} & \multirow{2}{*}{$\begin{array}{c}\text { Zn-foliar } \\
\text { (g/fed) }\end{array}$} & \multicolumn{4}{|c|}{ Macronutrients (\%) } & \multirow{2}{*}{$\begin{array}{c}\begin{array}{c}\text { Micronutrient } \\
(\mathrm{mg} / \mathrm{kg})\end{array} \\
\mathrm{Zn}\end{array}$} \\
\hline & & $\mathrm{N}$ & $\mathrm{P}$ & $\mathrm{K}$ & $S$ & \\
\hline \multirow{3}{*}{0} & 0* & 2.86 & 0.33 & 1.96 & 0.39 & 39.06 \\
\hline & 450 & 2.93 & 0.35 & 2.04 & 0.41 & 44.54 \\
\hline & 900 & 3.05 & 0.36 & 2.10 & 0.44 & 47.15 \\
\hline \multicolumn{2}{|c|}{ Mean } & 2.94 & 0.35 & 2.03 & 0.41 & 40.91 \\
\hline \multirow{3}{*}{250} & 0 & 3.22 & 0.40 & 2.09 & 0.47 & 43.92 \\
\hline & 450 & 3.37 & 0.43 & 2.18 & 0.49 & 49.08 \\
\hline & 900 & 3.41 & 0.45 & 2.23 & 0.50 & 52.12 \\
\hline \multicolumn{2}{|c|}{ Mean } & 3.33 & 0.43 & 2.17 & 0.49 & 49.70 \\
\hline \multirow{3}{*}{500} & 0 & 3.48 & 0.47 & 2.21 & 0.54 & 49.56 \\
\hline & 450 & 3.57 & 0.48 & 2.29 & 0.56 & 54.92 \\
\hline & 900 & 3.61 & 0.50 & 2.36 & 0.59 & 57.35 \\
\hline \multicolumn{2}{|c|}{ Mean } & 3.55 & 0.48 & 2.29 & 0.56 & 55.28 \\
\hline \multirow{3}{*}{750} & 0 & 3.79 & 0.54 & 2.35 & 0.60 & 53.76 \\
\hline & 450 & 3.91 & 0.59 & 2.42 & 0.64 & 57.45 \\
\hline & 900 & 4.07 & 0.62 & 2.51 & 0.67 & 62.89 \\
\hline \multicolumn{2}{|c|}{ Mean } & 3.92 & 0.58 & 2.43 & 0.68 & 60.37 \\
\hline \multirow{3}{*}{$\begin{array}{l}\text { L.S.D. at } \\
0.05\end{array}$} & $S$ & 0.31 & 0.02 & 0.05 & 0.03 & 0.92 \\
\hline & $\mathrm{Zn}$ & 0.53 & 0.05 & 0.09 & 0.06 & 1.32 \\
\hline & $\mathrm{S} \times \mathrm{Zn}$ & 0.39 & 0.03 & 0.05 & 0.03 & 1.44 \\
\hline
\end{tabular}

*The control treatment

Summation of nutrients uptake by lentil seeds revealed that all combined treatments produced significant increases as compared with the control treatment, particularly in case of $\mathrm{P}, \mathrm{S}$ and $\mathrm{Zn}$. In addition, the highest rates of S-soil application and Zn-foliar spray $(750 \mathrm{~kg} \mathrm{~S} / \mathrm{fed}+900 \mathrm{~g} \mathrm{Zn} / \mathrm{fed})$ resulted in higher contents of nutrients taken up by lentil seeds as compared with the control treatment. These results are in agreement with those of Negm et al. (2001), Negm et al. (2002b) and Fathi et al. (2005).

The highest rates of applied $\mathrm{S}(750 \mathrm{~kg} / \mathrm{fed})$ and $\mathrm{Zn}(900 \mathrm{~g} / \mathrm{fed})$ together caused higher seed contents of $\mathrm{N}, \mathrm{P}, \mathrm{K}, \mathrm{S}$ and $\mathrm{Zn}$, with increase percentages reached $42.31,87,88,28.06,71.79$ and $61.01 \%$, respectively, as compared with the control treatment.

\section{b. Nutrient recoveries or $S$-soil application efficiency:}

Data in Table (8) show the values of sulphur efficiency to provide the plant with a nutrient according to obtaining the percentage of consumed portion of the nutrient from the sulphur to the added quantity of that nutrient. Concerning the first rate of elemental sulphur $(250 \mathrm{~kg} / \mathrm{fed}), \mathrm{S}$-efficiency to provide plan with $\mathrm{K}$ was relatively low $(23 \%)$, then it increased with $\mathrm{Zn}$ and $\mathrm{N}$ to 29 and $30 \%$, respectively, however, higher efficiency values were recorded with $\mathrm{P}$ and $\mathrm{S}$ (40 and 39\%, respectively). Also, $\mathrm{P}$ and $\mathrm{S}$ utilization percentages due to the applied sulphur were relatively high (104 and 99\%,

Fayoum J. Agric. Res. \& Dev., Vol. 21, No.1, January, 2007 
respectively, when $S$ was added at a rate of $500 \mathrm{~kg} \mathrm{~S} / \mathrm{fed}$ ) and achieved their highest values, i.e., 157 and $142 \%$, respectively. with increasing the rate of applied sulphur to $750 \mathrm{~kg} / \mathrm{fed}$.

Table (8): The suggested sulphur efficiency according to the studied season for lentil seeds utilization macro and micronutrients.

\begin{tabular}{|c|c|c|c|c|c|}
\hline \multirow{2}{*}{$\begin{array}{c}\text { Nutrient } \\
(\mathrm{kg})\end{array}$} & $\begin{array}{c}\text { Total nutrient uptake by seeds } \\
(\mathrm{kg} \text { or g/fed) }\end{array}$ & \multicolumn{4}{|c|}{ Rate of S-soil application (kg/fed) } \\
\cline { 3 - 6 } & Amount utilized from sulphur & 15.23 & 19.86 & 26.60 & 31.75 \\
\hline \multirow{2}{*}{$\mathrm{N}$} & Sulpher efficiency \% & -- & 30.40 & 74.65 & 105.47 \\
\cline { 2 - 6 } & Amount utilized from sulphur & 1.76 & 2.47 & 3.59 & 4.52 \\
\cline { 2 - 6 } $\mathrm{P}$ & Sulpher efficiency \% & -- & 40.34 & 103.98 & 156.82 \\
\hline \multirow{2}{*}{$\mathrm{K}$} & Amount utilized from sulphur & 10.44 & 12.89 & 16.89 & 19.69 \\
\cline { 2 - 6 } & Sulpher efficiency \% & -- & 23.47 & 61.78 & 88.60 \\
\hline \multirow{2}{*}{$\mathrm{S}$} & Amount utilized from sulphur & 2.08 & 2.89 & 4.13 & 5.03 \\
\cline { 2 - 6 } & Sulpher efficiency \% & -- & 38.94 & 98.56 & 141.83 \\
\hline \multirow{2}{*}{$\mathrm{Zn}$} & Amount utilized from sulphur & 0.21 & 0.27 & 0.38 & 0.45 \\
\cline { 2 - 6 } & Sulpher efficiency \% & -- & 28.57 & 80.95 & 114.28 \\
\hline
\end{tabular}

Zinc, nitrogen and potassium utilization percentages increased progressively with increasing rate of the applied $\mathrm{S}$, where $\mathrm{S}$ efficiency at the rates 500 and $750 \mathrm{~kg} \mathrm{~S} /$ fed were as follows: Zn (81-114\%) > N (75-105\%) > $\mathrm{K}(62-89 \%)$. This means that the efficiency of $\mathrm{S}$ for enhancing the availability and uptake of these nutrients following the descending order of $\mathrm{Zn}>\mathrm{N}>\mathrm{K}$. Generally, it could be concluded that sulphur application enhancing the released nutrients from non-available forms to available ones and consequently their uptake by lentil seeds with different values of S-efficiency.

The beneficial effects of $\mathrm{S}$ application in such soil calcareous in nature may be due to the effective role of sulphur on decreasing soil $\mathrm{pH}$ via release of sulphate during the biological oxidation of sulphur and this had a beneficial effect on the multiplication and activity of microorganisms. In this regard, Azzazy et al. (1994) reported that adding sulphur to the calcareous soil, in the occurrence of energy source such as organic materials, produced better results for releasing nutrients and their uptake by plants.

\section{REFERENCES:}

Abd El-Halim,A.K. (2001): Effect of sluphur application on the main morphological, physical, chemical and microbiological properties of soils and on production of some field crops. M.Sc. Thesis, Fac. of Agric, Alex. Univ., Egypt.

Azzazy, M.A.; M.A. Maksoud and F.H. Laila (1994): Biological farming and sulphur application for improvement of $\mathrm{Fe}, \mathrm{Zn}$ and $\mathrm{Mn}$ uptake by guava (Psidium guajava L.) seedlings grown on a calcareous soil. Annals Agric. Sci., Ain Shams Univ., Cairo, 39(2): 731-738.

Awad, E.A.M; M.M. Mostafa and A.M. Helmy (2000): Macro and Micronutrient contents of maize plant as affected by the application of some organic wastes and sulphur. Zagazig J. Agric. Res., 27(4): 1015-1029.

Awadalla, A.A.; M.M. Salib and Sh.B. Ibrahim (2003): Response of maize yield grown on calcareous soil to some organic and inorganic amendments under irrigation with saline drainage water. Egypt. J. Appl. Sci., 18 (3): 366-381.

Ayers, R.S. and D.W. Westcot (1985): Water quality for agriculture, irrigation and drainage. Paper No. 29, FAO, Rome, Italy.

Fayoum J. Agric. Res. \& Dev., Vol. 21, No.1, January, 2007 
RESPONSE OF A NEWLY RECLAIMED CALCAREOUS SOIL AT... 75

Basyouny, E.A. (2005): Effect of chelated micronutrients combined with sulphur or organic manures on wheat production grown on a calcareous soil. Egypt. J. Appl. Sci., 20 (9): 375-387.

Black, C.A.; D.D. Evans; L.E. Ensminger; J.L. White and F.E. Clark (1965): Methods of Soil Analysis. Amer. Soc. Agron. Inc., Pub., Madison, Wisc., USA.

Chapman, H.D. and P.F. Pratt (1961): Methods of Analysis for Soils, Plants and Waters. Univ. Calif., Division of Agric. Sci., USA.

El Kabbany, E.A.Y.; M.A. Mahrous; A.A. Hamada and A.A. Darwech (1996): Response of wheat to foliar application of zinc, iron and copper. Proc. $7^{\text {th }}$ Conf. Agron., 9-10 Sep., pp. 1-9.

Fathi, A.I.; E.M. Gaffar; N.H. Omer and S.S. Behairy (2005): Interaction effect of sulphur and phosphorus on yield and nutrient contents of lentil. Egypt. J. Appl. Sci., 20 (2): 340-349.

Ghaly, S.; A.O. Osman and M. Moursy (1992): Application of different ratios of $\mathrm{Zn}, \mathrm{Mn}$ and $\mathrm{Fe}$ on corn grown in certain alluvial and calcareous soils. Egypt. J. Agric. Res., 70: 683-691.

Huang, W.Z.; J.J. Schoenau and K. Elmy (1992): Leaf analysis as a guide to sulphur fertilization of legumes. Commun. Soil Sci. Plant Anal., 23: 10311042.

Jackson, M.L. (1973): Soil Chemical Analysis. Prentice Hall of India Private Limited, New Delhi, Indian.

Johnson, G.V. and B.B. Tucker (1982): OSV soil test calibration, Okla. State Univ. Coop. Ext. Serv. Facts 2225.

Jones, J.B.; B. Wolf and H.A. Mills (1991): Plant Analysis Handbook, Micro, macro Publishing Inc., Georgia, USA.

Krishnareddy, S.V. and I.P.S. Ahlawat (1996): Growth and yield response of lentil cultivars to phosphorus, zinc and biofertilizers. J. Agron. \& Crop Sci., 177: 4959.

Lindsay, W.L. and W.A. Norvell (1978): Development of DTPA soil test for Zn, Fe, Mn and Cu. Soil Sci. Soc. Am. J., 42: 421.

Mostafa, M.M. (2000): Nutrients availability as affected by applying agro-industrial wastes and sulphur to saline and non-saline soils. Egypt. J. Appl. Sci., 15 (11): 385-397.

Moussa, B.I.; M.S.A. Dahdoh and H.M. Shehata (1998): Interaction effect of some micronutrients on yield, elemental composition and oil content of peanut. Commun. Soil Sci. Plant Anal., 27 (2-8): 1995.

Naire, K.P.P and N.C. Khuble (1990): Different response of wheat and barley genotypes to substrate induced salinity under north Indian conditions. Exp. Agric., 26: 221-225.

Negm, M.A.; M.H. Esyed and A.S. Ahmed (2001): Effect of treated compost and sulphur application to a calcareous soil on soil properties and cereal production. The $1^{\text {st }}$ International Conf. on Biotechnology Application for the Arid Regions, 9-11 April 2001, Kuwait Inst. Sic. Res., Al Kuwait, Abs No. 30.

Negm, M.A.; H. El-Zaher; M.M. Abd Elghani and M.M. Salib (2002a): Effect of commercial compost (Biotreasure) and sulphur added to a calcareous soil on: 1) Soil properties and fertility. Minufiya J. Agric. Res., 27 (2): 369-379.

Negm M.A.; H. El-Zaher; M.S. Awad and M.H. El-Sayed (2002b): Effect of commercial compost (Biotreasure) and sulphur added to a calcareous soil on (II) Cereal productivity and nutrient uptake. Minufya J. Agric. Res., 27 (2): 381-390.

Fayoum J. Agric. Res. \& Dev., Vol. 21, No.1, January, 2007 
Page, A.L.; R.H. Miller and D.R. Keeny (1982): Methods of Soil Analysis. II: Chemical and Microbiological Properties. Soil Sci., Amer., Madison, Wisconsin, USA.

Ray, R.K. and R.S. Tripathi (1985). Effect of irrigation and phosphorus on yield, nodulation, water use efficiency and nutrient concentrations in chickpea. Indian J. of Agronomy, 30: 401-407.

Salama, F.S.A.; I.M. Salim and N.R. Tolbah (2003): Studies on the effect of zinc application on wheat crop. J. Agric. Sci. Mansoura Univ., 28 (2): 1557-1566.

Shahin, R. and A.S. Suliman (1998): Transformation of sulphur-blended urea and ammonia volatilization in sandy soils. Fayoum J. Agric. Res. \& Dev., 12 (1): 66-77.

Singh, Y.P.; C.P.S. Chauhan and R.K. Gupta (2000): Effect of sulphur, phosphorus and inoculation on growth, yield and sulphur utilization by lentil. Indian J. of Agric. Sci., 70: 491-493.

Singh, S.P.; D.S. Chauhan and Y.P. Singh (2002): Response of lentil (lens culinaris) cultivars to sources and levels of sulphur. Indian J. of Agronomy, 47: 94-97.

Snedecor, G.W. and W.G. Cochran (1971): Statistical Methods $6^{\text {th }}$ Ed., Iowa State Univ. Press., Ames.

Soil Survey Staff (1999): Soil Taxonomy. A Basis System of Soil Classification for Making and Interpreting Soil Surveys. Second Edition, U.S. Department of Agriculture, Natural Resources Conservation Service, U.S.D.A., Agriculture Handbook No. 436.

Sommers, L.B. and D.W. Nelson (1972: Determination of total phosphorus in soils; A rapid perchloric acid digestion procedure. Soil Sci. Soc. Amer. Proc., 36: 902-904.

Soltanpour, P.N. and A.B. Schwab (1977): A new soil test for simultaneous extraction of macronutrients in alkaline soils. Comm. Soil Sc. and Plant Anal., 8: 195.

Sys, C. and W. Verheye (1978): An attempt to the evaluation of physical land characteristics for irrigation to the FAO framework for land evaluation. Int. 1, Trai. Cent. Post Grad. Soil Sci., Ghent, Belgium.

Takker, P.N. and C.D. Walker (1993): The distribution and correction of zinc deficiency. In: Zinc in Soils and Plants. Robson, A.D. (ed.), Kluwer Acad. Publ., Dordrecht, pp. 151-165, The Netherlands.

Tomar, S.K.; P. tripathi and L. Rajput (2000): Effect of genotype, seeding method and di-ammonium phosphate on yield and protein and nutrient uptake by lentil (Lens culinaris). Indian J. of Agronomy, 45: 148-152.

Varavipour, M.; R. Hassan and D. Singh (1999): Effect of applied phosphorus sulphur and zinc on yield and uptake parameters of wheat and soybean grown on a loamy sand. Indian J. of Agric. Sci., 69(1): 1-4.

Wahdan, A.A.; A.A. Awadalla and M.M. Mahmoud (2006): Response of wheatmaize cropping sequence in a calcareous soil to some mineral or chelated micronutrients forms added to soil in combination with sulphur and organic manures. Fayoum J. Agric. Res. \& Dev., 20 (1): 25-39.

Fayoum J. Agric. Res. \& Dev., Vol. 21, No.1, January, 2007 
RESPONSE OF A NEWLY RECLAIMED CALCAREOUS SOIL AT ... 77 إستجابة أرض جيرية مستصلحة حليثا عند الحافة الثرقية لمنخفض الفيوم لمعالجة كيميائية زراعية لتعضيد تنميتها زراعيا

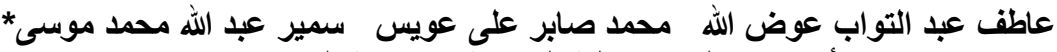

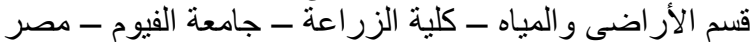

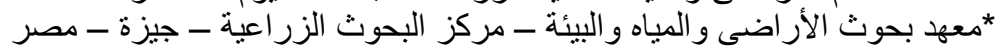

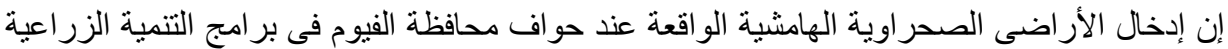

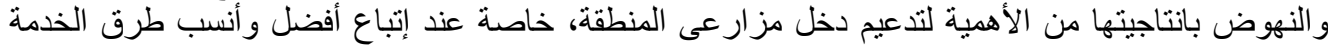

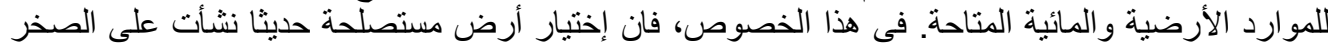

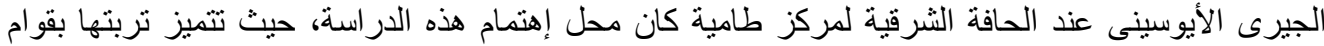

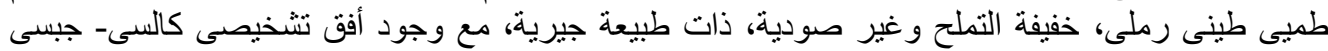
(Calcigypsic horizon)

Typic Calcigypsids, fine loamy, mixed, hyperthermic, moderately deep.

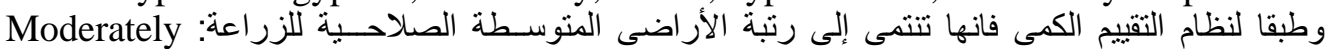

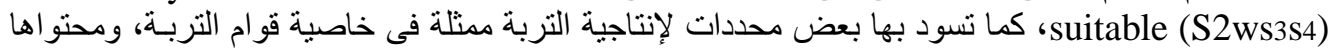
من

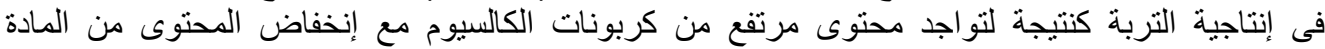

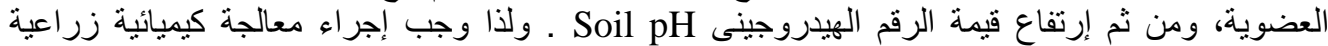

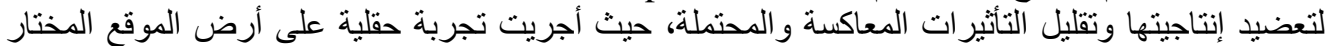

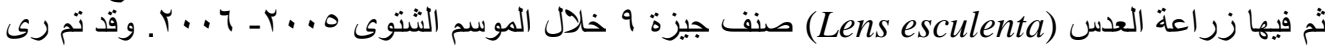

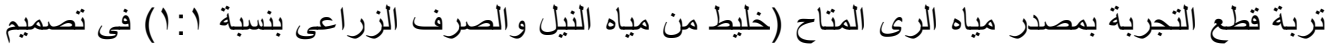

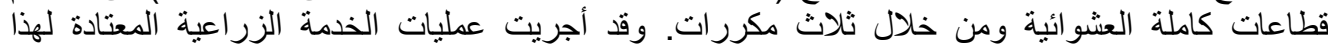

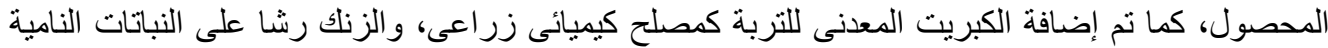

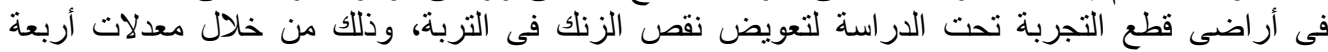

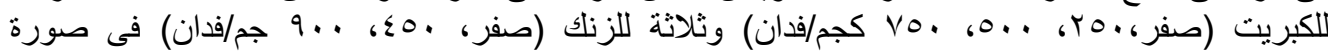

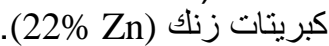

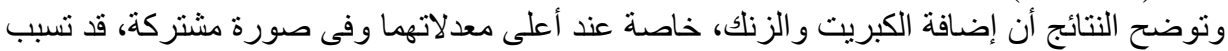

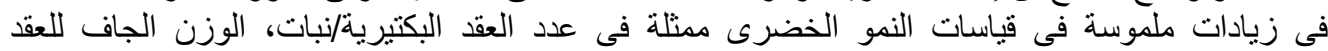

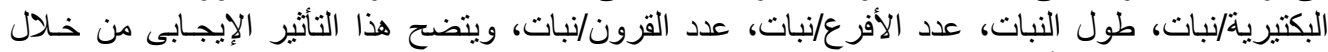

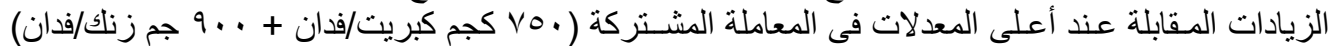

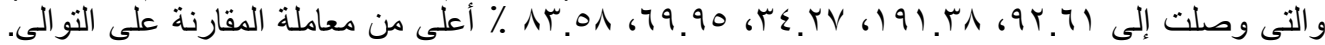

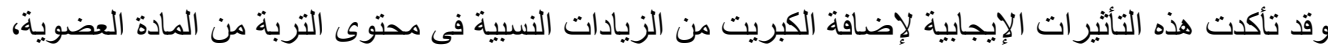

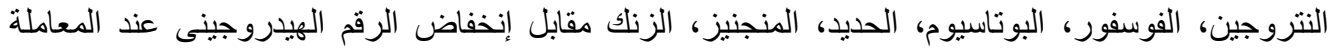

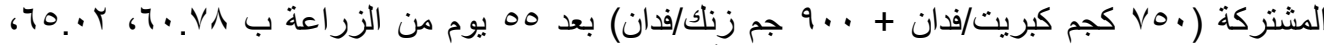

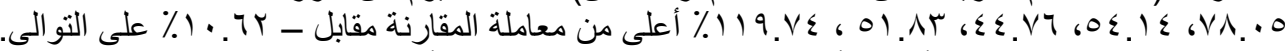

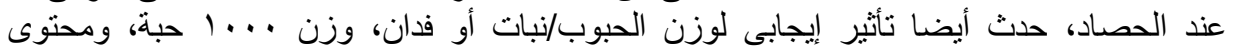

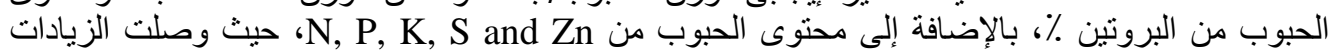

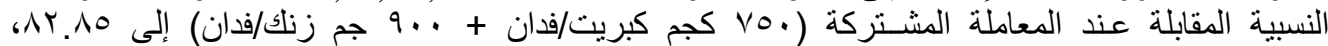

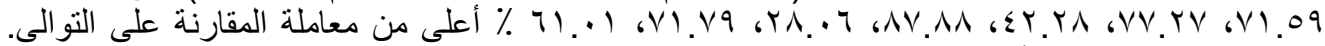

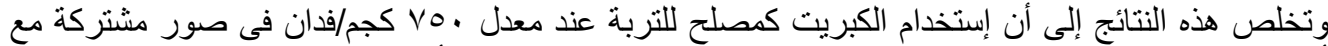

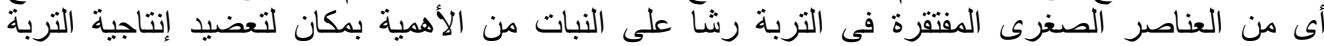

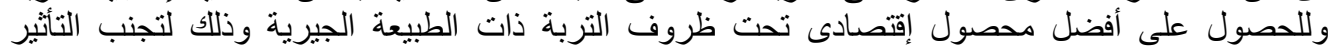
المبانثر والمعاكس لمكون المكل

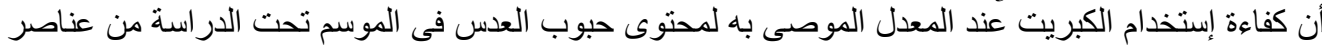
S. S, P, K and S

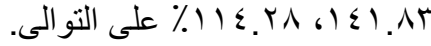

Fayoum J. Agric. Res. \& Dev., Vol. 21, No.1, January, 2007 